\title{
Size MATTERs! Body HeIGHT AND LABOR MARKET DISCRIMINATION: A CROSS- EUROPEAN ANALYSIS
}

Francesco Cinnirella and Joachim Winter 


\title{
Size Matters! Body Height and Labor Market Discrimination: A Cross-European Analysis
}

\author{
Francesco Cinnirella* \\ Ifo Institute for Economic Research, Munich, and CESifo \\ Joachim Winter \\ Department of Economics, University of Munich, CESifo, \\ and MEA, University of Mannheim
}

\begin{abstract}
Taller workers earn on average higher salaries. Recent research has proposed cognitive abilities and social skills as explanations for the height-wage premium. Another possible mechanism, employer discrimination, has found little support. In this paper, we provide some evidence in favor of the discrimination hypothesis. Using a cross section of 13 countries, we show that there is a consistent height-wage premium across Europe and that it is largely due to occupational sorting. We show that height has a significant effect for the occupational sorting of employed workers but not for the self-employed. We interpret this result as evidence of employer discrimination in favor of taller workers. Our results are consistent with the theoretical predictions of recent models on statistical discrimination and employer learning.
\end{abstract}

JEL Classification: J24, J31, J71

Keywords: Height, Wage Premium, Discrimination, Cognitive Functions, Occupational Sorting

We thank Sascha Becker and John Komlos for their comments on an earlier version of this paper. Comments of Axel Börsch-Supan, Hendrik Jürges, Ludger Woessmann and the participants at the CESifo Area Conference on Employment and Social Protection are also gratefully acknowledged. All remaining errors are those of the authors.

This paper uses data from SHARE waves $1 \& 2$, as of December 2008. SHARE data collection in 2004-2007 was primarily funded by the European Commission through its 5th and 6th framework programmes (project numbers QLK6-CT-2001- 00360; RII-CT2006-062193; CIT5-CT-2005-028857). Additional funding by the US National Institute on Aging (grant numbers U01 AG09740-13S2; P01 AG005842; P01 AG08291; P30 AG12815; Y1-AG-4553-01; OGHA 04-064; R21 AG025169) as well as by various national sources is gratefully acknowledged (see http://www.share-project.org for a full list of funding institutions).

${ }^{*}$ Corresponding author. Address: Ifo Institute for Economic Research, Poschingerstr. 5, 81679 Munich, Germany; phone: +49 899224 1366; e-mail: cinnirella@ifo.de 


\section{Introduction}

In the last few years, much scholarly research has been devoted to explaining a striking empirical regularity in labor economics: Taller workers earn more than shorter ones. The magnitude of the height-wage premium is not trivial - one inch (about $2.54 \mathrm{~cm}$ ) increase in height is associated with a wage increase of about one to two percent (Case and Paxson, 2008). The existing literature has largely focused on cognitive abilities and social skills as explanations for the height-wage premium (Case and Paxson, 2008; Persico, Postlewaite, and Silverman, 2004). Another possible mechanism, namely employer discrimination, has found little support. In fact, very few studies relate the height-wage premium to a problem of statistical discrimination (Loh, 1993; Magnusson, Rasmussen, and Gyllensten, 2006; Hübler, 2006). In this paper, we analyze the relationship between height and labor market outcomes using cross-section data for 13 European countries ${ }^{1}$ and provide evidence in favor of the discrimination hypothesis.

We analyze data on older European workers from the first two waves of the Survey of Health, Ageing, and Retirement in Europe (SHARE) and show that there is a substantial height-wage premium across Europe. Similarly to the finding of Case, Paxson, and Islam (2008), our analysis suggests that the height-wage premium is to a large extent due to sorting of taller workers into higher status occupations. We also show that this result holds when we control for cognitive abilities. More importantly, we assess whether employers discriminate in favor of taller workers by comparing occupational sorting of employed workers with that of the self-employed. A similar empirical strategy was adopted by Biddle and Hamermesh (1998) who investigated whether employer discrimination was the source of the wage premium associated with beauty.

The logic behind this empirical approach is straightforward. We take two otherwise similar groups which differ by the fact that the self-employed are

\footnotetext{
1 The height-wage premium has been mainly studied using data for Britain and the U.S. (Case and Paxson, 2008; Case, Paxson, and Islam, 2008; Persico, Postlewaite, and Silverman, 2004; Heineck, 2008). Exceptions are the studies of Hübler (2006) and Heineck (2005, 2009) who analyze the height-wage premium for Germany.
} 
not subordinated to an employer. All other factors being constant, finding a height effect for the employed workers occupational sorting, but not finding any height effect for the occupational sorting of the self-employed would imply that employer discrimination plays a role in the employees' sorting. Indeed, we find that height plays a significant role only in the occupational sorting of employed workers, whereas it plays no role in the sorting of the self-employed. This result suggests that employer discrimination contributes to the height-wage premium and that body height belongs to those observable characteristics used by employers to statistically discriminate between workers. ${ }^{2}$ In addition, we also speculate that there is no full employer learning (Altonji and Pierret, 2001) as we find that the height-wage premium is still substantial for a relatively old age-group (as we shall explain below, our data are for individuals mostly aged 50 and older).

Several potential channels and identification strategies have been put forward in the literature to explain the height-wage premium. Studies in social psychology stress factors such as self-esteem (Judge and Cable, 2004; Young and French, 1996) and social dominance (Hensley, 1993). In particular, the study of Judge and Cable (2004) elaborates on a theoretical model of physical stature and career success offering two possible explanations, namely social-esteem and self-esteem, where the former is the positive evaluation and regard of the society. They also stress that physical stature is more likely to play a role in those occupations where social-interactions are more important.

Persico, Postlewaite, and Silverman (2004) exploit the intra-individual variation of height between adolescence and adulthood in order to identify at which stage of development physical stature determines the height-wage premium. In particular, height for the same individual was measured at age 7, 11, 16 and 33. The authors find that what matters for labor market outcomes is not adult height but rather teen height. They argue that being tall at that particular point of development is positively related with participation to

\footnotetext{
${ }^{2}$ Generally, amount and quality of education, race, and gender are used to discriminate between workers. See Altonji and Blank (1999) for a survey on labor market discrimination. See also Hamermesh and Biddle (1994); Hamermesh and Parker (2003); Hamermesh (2006) on labor market returns to beauty and employer discrimination.
} 
social activities ${ }^{3}$ which enhance social skills that will be successively rewarded in the labor market.

In a more recent paper, Case and Paxson (2008) stress the link between height and intelligence. They show that already at age 3, and throughout childhood, taller children have higher cognitive ability. They argue that prenatal environment and nutrition during childhood might play an important role in determining both physical stature and cognitive ability. They conclude that taller workers earn more because they are more intelligent. In a follow-up paper, using several waves of the British Household Panel Survey, Case, Paxson, and Islam (2008) show that half of the height-wage premium can be explained by the association between height and educational attainment - consistent with the previous result that taller individuals have higher cognitive ability - whereas half of the remaining premium is explained by taller workers sorting into higher status occupations and industries. Case and Paxson also acknowledge the possibility of statistical discrimination in favor of taller workers "[...] at least until employers have time to learn about employees abilities" (Case and Paxson, 2008, p. 529). In our paper, we shall make a stronger case for employer discrimination as we show that discrimination has a persistent effect observable until the end the workers' career path.

The paper is structured as follows. In section 2, we describe the SHARE data and the construction of our dataset, and we provide descriptive statistics of the variables of interest. In section 3, we estimate the size of the height-wage premium in Europe and show to which extent it is explained by occupational sorting. In Section 4 we compare occupational sorting for employed workers and self-employed in order to assess the role of employer discrimination. We also provide some robustness checks and sensitivity analysis. Section 5 concludes.

\footnotetext{
${ }^{3}$ The authors think of athletics, school clubs, and dating as examples of social activities.
} 


\section{Data}

We use the first two waves (2004/05 and 2006/07) of the Survey of Health, Ageing, and Retirement in Europe (SHARE) which collects information on earnings, health, and various socio-economic variables for individuals aged $50+$ across 14 European countries. ${ }^{4}$ We use data for 13 countries as information on Israel was not suitable for our analysis. Data on the sampled respondent's partner were collected independently of age, therefore a few respondents are younger than 50. We pool the entire wave 1 of the survey (year 2004/05) and the "refresher" sample of wave 2 (year 2006/07), so to have a pooled sample in which we observe each individual once. The countries used in our study represent different regions of Europe, namely Northern Europe (Denmark and Sweden), Western Europe (Austria, Belgium, France, Germany, Netherlands, Switzerland), Southern Europe (Greece, Italy, and Spain), and Eastern Europe (Czech Republic and Poland). ${ }^{5}$ Since we are interested in establishing the source of the height-wage premium, we initially focus on respondents below age 65 who report having income from work. ${ }^{6}$

Physical stature is expected to start shrinking after the age of 50 (Tanner, 1989). Yet, to the extent that the shrinking process is not systematically different across countries (and there is no such evidence), it should not affect the interpretation of our results. We exclude civil servants whose wage schedule strongly depends on tenure (but our results do not change quantitatively when we include civil servants as employed workers). Finally, in order to be able to assess whether the height-wage premium is due to discrimination, we focus exclusively on males as working women may be also subject to gender discrimination. ${ }^{7}$ In Table 1 , we show the number of observations we obtain after imposing these restrictions (as well as availability of the dependent and

\footnotetext{
${ }^{4}$ SHARE was designed in order to be comparable with the U.S. Health and Retirement Study (HRS) and the English Longitudinal Study of Ageing (ELSA). For more details about the dataset, see Börsch-Supan and Jürges (2005). A recent cross-country study of labor market outcomes that also uses SHARE data is Brunello, Fort, and Weber (2009).

${ }^{5}$ Czech Republic and Poland were included only in wave 2 of the survey.

${ }^{6}$ In the subsequent estimates of occupational sorting for self-employed, we relax the restriction of having reported income from work.

7 Persico, Postlewaite, and Silverman (2004) followed the same approach.
} 
independent variables which are discussed below). The country-specific number of observations ranges from a minimum of 121 in Austria to a maximum of 588 in Sweden. The total number of observations is just under 4,200.

Regarding the dependent variable, we use information on gross earnings reported by the respondent. Since respondents report also the actual number of hours worked per week, we can compute hourly wages. ${ }^{8}$ In order to make them comparable across countries, hourly wages are deflated by OECD comparative price levels defined as the ratios of PPPs to exchange rates (OECD, 2008). It is also important to note that, in contrast to most other studies, we can observe the exact date when the respondent started his last job (this information is reflected in the variable tenure).

Crucially for our analysis, the SHARE survey provides information on self-reported height and weight, as well as numerous variables about the health condition of the respondent. Since our main aim is to assess whether employers discriminate according to height, we need to define when an individual can be considered tall or short. In this sense, body height can be viewed as a country-specific variable. Throughout the paper, if not otherwise specified, we consider a person tall if his physical stature is above the country-specific sample median. ${ }^{9}$ As shown in Table 2 , the share of tall employed workers is 55 percent whereas the share of tall self-employed individuals is slightly above 60 percent. In Figure 1 we show the relationship between log hourly wage and height across Europe. With the only exception of Poland, employed workers whose stature is above the country-specific median earn more than their shorter colleagues.

In order not to confound the effect of height with other physical appearance effects, our subsequent analysis controls for obesity which is coded as a dummy variable that takes the value of one for individuals with a body mass index (BMI) of 30 or higher (which is the standard definition of obesity). ${ }^{10}$

\footnotetext{
${ }^{8}$ We exclude from the regression analysis 23 observations with extreme values of the dependent variable, such as hourly wages below one Euro and above one thousand Euros.

${ }^{9}$ When we use height as a continuous variable, we obtain qualitatively similar results. We decided to use a median split to facilitate the interpretation of the results.

10 The BMI of an individual is computed as the weight in kilograms, divided by the square of height expressed in meters.
} 
Similarly to the study of De Luca, Mazzonna, and Peracchi (2009), which also uses the SHARE data, we include controls for several types of chronic diseases which could limit the respondent's earning capacities. ${ }^{11}$

Educational attainment is another variable that is country-specific. The respondents' highest educational attainment has been made comparable across countries using the ISCED-97 code. We then compute a binary variable for high education which takes on value one if the respondent attained at least a post-secondary education. ${ }^{12}$ Almost 30 percent of the workers in our sample have attained a post-secondary education, whereas the share increases to 34 percent for the self-employed (Table 2). The richness of the dataset allows us to include several controls for industry and occupation. In particular, we insert controls for 14 industries following the NACE code (Version 4, Rev. 1, 1993) created by the European Union and 9 occupational categories following the ISCO-88 code for the skill levels. ${ }^{13}$

The association between height and educational attainment is another empirical regularity which has attracted much attention (Cinnirella, Piopiunik, and Winter, 2009; Magnusson, Rasmussen, and Gyllensten, 2006; Lynn, 1989; Bielicki and Charzewski, 1983). Case, Paxson, and Islam (2008) find that half of the height-wage premium can be ascribed to the correlation between height and education. In Figure 2 we show the relationship between height and educational attainment as in our sample. On average, respondents with at least a post-secondary education are systematically taller than those with a lower educational attainment.

The SHARE dataset is quite valuable as it also contains measures of cognitive abilities. In particular, respondents perform tests on orientation in time, memory, verbal fluency, and numeracy. ${ }^{14}$ These tests for cognitive

\footnotetext{
${ }^{11}$ These are high blood pressure, high blood cholesterol, stroke, diabetes, chronic lung disease, and cancer.

${ }^{12}$ In terms of the ISCED-97 code, the binary variable is one if the respondent falls in category 4,5 , or 6 .

13 The 14 industry categories are agriculture, mining, manufacturing, public utilities, construction, trade, hotel, transportation, banking, real estate, public administration, education, health, and other; the 9 occupational categories are manager, professionals, technician, clerk, service, skilled agricultural worker, craft, blue-collar, and unskilled.

${ }^{14}$ Respondents were also asked to rate subjectively their reading and writing skills.
} 
abilities are similar to those performed in HRS and ELSA. In the test of orientation, the interviewed is asked about date and day of the week. Given the low variance of the answers (at least in our sample of individuals who are still working), we do not use this dimension of cognitive ability but focus on the tests of memory, verbal fluency, and numeracy.

In the memory test, respondents are asked to listen to a sequence of ten items. Respondents have to recall the list immediately after listening and then a second time after the fluency and numeracy tests. We use the scores of the delayed recall as they display a larger variance. In particular, we compute a dummy variable for good memory which takes on value one if the score is above the median. The test of verbal fluency consists of listing in one minute as many different names of animals as possible. For the regression analysis we generate a dummy variable where the positive outcome indicates individuals whose scores is above the median. In Figure 3 we show the positive association between height and cognitive abilities, in particular the relationship with the results of the word fluency test and the memory test.

Numerical abilities were assessed by asking a sequence of questions of different difficulty. Respondents who answered correctly to the first question were asked a more difficult one, and in case of correct answer, they were asked a third final question. Those who failed the first question were asked an easier question. Thus, the best score would be to answer correctly to three questions of increasing difficulty, whereas respondents who scored worst were those who failed the first and the second question. ${ }^{15}$ We compute four dummy variables which comprise the full spectrum of numeracy abilities revealed by the test. ${ }^{16}$ Among the employed workers, only 33 percent reached the maximum score in numeracy; for the self-employed the share is equal to 36 percent (see Table 2).

\footnotetext{
15 The most difficult question is the following: "Let's say you have 2000 Euro in a saving account. The account earns ten per cent interest each year. How much would you have in the account at the end of the two years?" Possible answers are 2420, 2020, 2040, 2100, 2200, and 2400 Euros.

${ }^{16}$ As already mentioned, respondents who failed to answer the first question were asked a second question of minor difficulty. We ignore the performance on that second question given the large number of correct answers.
} 


\section{The height-wage premium across Europe}

The first step of our empirical analysis is to assess existence and size of the height-wage premium across the 13 European countries in our sample. We estimate a standard Mincerian wage equation using a linear specification with the logarithm of hourly wage, $w$, as dependent variable:

$$
w_{i}=\boldsymbol{x}_{i} \boldsymbol{\beta}+u_{i}
$$

The (row) vector of explanatory variables, $\boldsymbol{x}$, includes our variables of interest (height and measures of cognitive ability), a constant, and additional control variables. The vector $\boldsymbol{\beta}$ contains the coefficients we estimate by OLS. ${ }^{17}$

In Table 3, we show four different specifications in which we sequentially introduce more controls. In the base specification (column 1) where we control only for country fixed effects, taller workers earn around 8 percent more than their shorter colleagues. As can be seen in the successive specifications, cognitive abilities in all three dimensions (numeracy, memory and verbal fluency) are strongly correlated with earnings. Most importantly, controlling for cognitive abilities reduces the height-wage premium by about 30 percent. $^{18}$ Yet, what practically reduces to zero the height-wage premium is the set of occupational controls (column 4). In fact, although the point estimate of the effect of height is still positive, the coefficient is not statistically different from zero. This result is similar to the finding of Case, Paxson, and Islam (2008) whose study focused exclusively on Britain: They show that half of the height-wage premium is explained by higher educational attainment, whereas half of the remaining premium is explained by selection into higher status occupations. It is also important to note that our model can explain almost half of the variation in log hourly wage.

\footnotetext{
17 The error term $u$ is not necessarily independent of all the elements of $\boldsymbol{x}$, but as discussed below, we are not interested in estimating causal effects; rather, we interpret the estimated coefficients as conditional correlations.

18 Clearly, cognitive abilities might be endogenous with respect to education and the type of job performed. Since we are interested in the effect of height and not in the causal effect of cognitive abilities, endogeneity is not a problem.
} 
These results clearly show that there is a consistent height-wage premium across Europe and that this premium is largely explained by occupational sorting. The relevant question at this point is: What is the mechanism that generates occupational sorting by height? Can we exclude, as it was done by the most recent literature, employer discrimination? The fact that taller people select into higher status job does not necessarily exclude the existence of labor market discrimination. In order to analyze whether there is employer discrimination, in the next section we compare occupational sorting of employed workers with a sample of self-employed who, by definition, cannot be subject to employer discrimination.

\section{Occupational sorting}

In this section, we aim to assess whether occupational sorting by height is due to employer discrimination by comparing employed with self-employed workers. The empirical strategy is as follows. We define a categorical variable, skill, which indicates the intellectual skills embedded in the different occupations. We define four skill categories (Table 4); 'skill 1' is associated with the highest intellectual skills, and 'skill 4' with the lowest. This strategy is inspired by the study of Case and Paxson (2006, p. 26-27) in which they classified occupations according to the level of intellectual skills required following the Occupational Measures from the Dictionary of Occupational Titles for 1980 Census Detailed Occupations. Note that we aggregated the occupations in order to render the distribution of skills as similar as possible across the two groups, employed and self-employed. Table 4 shows how the four categories are distributed in the two groups. As one could have expected, within the self-employed the category skill 1 is larger (46 percent) as it is relatively more common to find managers and professionals among the selfemployed. Nevertheless, circa 28 percent of employed workers fall within the highest skill category. In a similar fashion, the group with the lowest skill ( skill 4) is larger for the employed workers. Notwithstanding the differences, 
the distribution of skills across the two groups is fairly similar. ${ }^{19}$

Given the categorical nature of the dependent variable, we estimate by Maximum Likelihood a standard multinomial logit model which specifies the response probabilities as

$$
\operatorname{Pr}\left(y_{i}=j \mid \boldsymbol{x}_{i}\right)=\frac{\exp \left(\boldsymbol{x}_{i} \gamma_{j}\right)}{1+\sum_{h=1}^{4} \exp \left(\boldsymbol{x}_{i} \gamma_{h}\right)},
$$

where $y_{i}$ denotes the skill level of an individual's job with $j \in\{1 \ldots, 4\}, \boldsymbol{x}_{i}$ is the (row) vector of covariates, and $\gamma_{j}$ are the parameters to be estimated. In the next subsection we present the estimates of occupational sorting models for employed workers and self-employed and compare the effect of height, assuming that the only difference between the two groups is the absence of an employer for the self-employed. Thus, if taller self-employed do not select into higher status occupations, this would suggest that occupational sorting by height among employed workers is driven by employer preference for taller employees. ${ }^{20}$

\subsection{Estimation results}

We start by showing estimates of the occupational sorting model for employed workers. In order to facilitate the interpretation of the estimates, we present the coefficients as Relative Risk Ratios which can be interpreted as the change in the probability of being in the indicated category with respect to the reference category. In our case, the reference category is skill 3. The results are presented in Table 5. As the log wage regression has already suggested, height plays a major role in employees' occupational sorting: Being taller than the country median increases the probabilities of being in category 1 by about 65 percent compared to category 3 and by 31 percent for

\footnotetext{
${ }^{19}$ In section 4.2 we shall conduct some formal tests in order to ensure that the employed and self-employed are effectively similar in terms of their skill distribution.

${ }^{20}$ Hübler (2006) analyzes the height-wage premium in Germany. Among various strategies to assess whether employer discrimination plays a role, he also compares employees with self-employed, though his dataset has only 170 observations for self-employed. In any case, our strategy differs substantially from that of Hübler as we apply the comparison to a model of occupational sorting and not to an earnings function.
} 
category 2. Cognitive abilities play also an important role and they show the expected gradient: The higher the cognitive ability measure, the higher is the probability of being in the most intellectual occupation. The same interpretation holds for the coefficients associated with high education.

In Table 6, we show the estimates for the self-employed. One should immediately note that there is no height effect in the sorting model for the self-employed. In fact, high education has the largest effect in explaining sorting among the self-employed. Therefore, we find that physical stature has a significant effect on occupational sorting only for employed workers, whereas it plays absolutely no role for the self-employed. This comparative analysis suggests that the occupational sorting by height we observe among employed workers might be determined by the employers who, all other things being constant, discriminate in favor of taller workers for jobs in which higher intellectual skills are required.

Judge and Cable (2004) argue that height plays a larger role in occupations where social interactions are more important. This point was also stressed by Heineck (2008). If this were the case, we would find a height effect also in the occupational sorting model for the self-employed, as the category with the highest intellectual skill comprises jobs such as "managers" and "professional occupations" where social interactions are indeed important. In this regard, in Table 7 we show the results of two Probit models where we separately estimate the probability of being an employed or self-employed professional. ${ }^{21}$ The share of professionals in the employed sample is about 14 percent, whereas the share of self-employed professionals is about 18 percent. The estimates show that being taller than the country-specific median increases significantly (at the 10 percent level) the probability of being an employed professional, whereas height has no effect for the self-employed professionals. Therefore, also for the highest occupational category - which is arguably highly comparable across employed and self-employed-height plays a role only for the employed professionals. In the next subsection we shall perform some formal tests in order to ensure that the two groups, employed

\footnotetext{
${ }^{21}$ In these two regressions we are comparing, for instance, lawyers or tax-advisers who are respectively employed or running their own business.
} 
and self-employed, are effectively similar in terms of their skills distribution.

\subsection{Skill distributions of the employed and the self- employed}

The fact that height has an effect for the occupational sorting of employed workers but not for the self-employed is used here as indicative evidence that employers discriminate in favor of taller workers. One could claim that employed and self-employed should not be compared as there are unobserved characteristics which are correlated with height and which differ systematically between the two groups. In fact, one could argue that the sample of self-employed is not a random sample, but rather a selected sample of the most (or less) skilled from the population. Yet, we can show that, at least for what concerns the observable variables at our disposal, employed and selfemployed do not differ systematically with respect to their skill distribution.

Let us consider the employed $(n=494)$ and the self-employed professionals $(n=204)$ used in the regression of Table 7 . We use a Mann-Whitney test in order to assess whether, with respect to their cognitive abilities, the two samples come from the same distribution. ${ }^{22}$ The null hypothesis is that the two distributions are equal. Firstly, we can show that the height distributions of the two groups are statistically equal (Figure 4, graph in the upper-left corner). The Mann-Whitney test cannot reject the null hypothesis and a further test suggests that the two samples are drawn from populations with the same median.

The graph in the upper-right corner of Figure 4 shows the distributions of the word fluency test for the two groups. One can see that the two distributions are slightly different and that employed professionals have a higher mode. Indeed, the test rejects the null hypothesis and suggests that the distribution of the employed professionals has a higher median.

In the bottom-left corner we presents the distributions of the memory test. In this case, the test cannot reject the null hypothesis and the test for

\footnotetext{
${ }^{22}$ It is important to note that the Mann-Whitney test is a non-parametric test, which means that it does not require assumptions about the form of the distribution of the variables.
} 
the median suggests that the two samples come from populations with the same median.

At last, in the bottom-right corner of Figure 4 we show the distributions of the numeracy test. The statistical test cannot reject the null hypothesis, which means that numerical abilities are distributed in the same way within the two groups. In fact, the dataset contains also information on self-rated reading and writing skills which go from "poor" to "excellent". In both cases, the Matt-Whitney test cannot reject equality of the two distributions. Therefore, employed and self-employed professionals seem to have different skill distributions only with respect to word fluency. In all other cases, namely numeracy, memory, self-rated reading and writing skills, the two groups do not show any significant difference.

These findings validate our "identification strategy" which, besides the large set of control variables at our disposal, is based on the fact that employed workers and self-employed differ uniquely by the fact that the latter are not subject to an employer. ${ }^{23}$

\section{Conclusion}

This paper contributes to the expanding literature on the height-wage premium in several ways. First, we show that across Europe there exists a consistent height-wage premium which can be largely ascribed to occupational sorting and only partially to the positive association between height and cognitive abilities. An employed worker whose height is above the countryspecific median has a probability of being in a high-skill occupation that is about 65 percent higher than that of a worker employed in a low-skill occupation. The main question we address in the paper is why taller workers, independently of their education and cognitive abilities, perform intellectually more demanding jobs and therefore are better paid.

In order to understand whether employed workers are discriminated on

\footnotetext{
${ }^{23}$ In fact, recent research suggests that the intergenerational link in self-employment is not primarily due to the acquisition of specific business human capital (Fairlie and Robb, 2007)
} 
the basis of their body height, we perform a comparative analysis. We consider a sample of self-employed individuals which is, in terms of skill distribution, as much similar as possible to the group of employed workers. The major difference between the two groups is that the self-employed, by definition, are not subordinated to an employer. We find that, in contrast to the case of the employed workers, height plays no role in occupational sorting for the self-employed. This result holds even when we exclusively focus on employed and self-employed professionals. We claim that these findings provide some compelling evidence in favor of the discrimination hypothesis.

These results are even more remarkable given the relatively advanced age $(50+)$ of the individuals in the SHARE dataset. It is reasonable to assume that the asymmetry of information about workers' productivity, which is the standard explanation for statistical discrimination, is not a major issue in our sample in which most of the respondents should have already revealed their productivity. Thus, we suggest three non-exclusive explanations for the occupational sorting by height found for the employed workers: (i) employers, independently of the observable workers' productivity, have an a priori strong preference for taller workers; (ii) short (prospective) workers on average do not apply for jobs where higher intellectual skills are required; (iii) short workers are statistically discriminated at the beginning of their career when they enter the labor market and, due to labor market rigidities, the initial effect of discrimination persists until the end of the workers' career path. In fact, there is some evidence that occupational sorting by height is more pronounced in Southern Europe (Greece, Italy, and Spain) where internal labor markets are allegedly more rigid and firing costs are relatively higher (Cahuc and Zylberberg, 2004, p. 736). ${ }^{24}$ This evidence, if confirmed, would support the hypothesis that there is statistical discrimination at the beginning of the career path when entering the labor market and that discrimination, despite employer learning, is more persistent where labor market are more rigid.

Our findings on employer discrimination are consistent with the theoretical framework provided by Altonji (2005). The author develops a model in

\footnotetext{
${ }^{24}$ Estimates are available upon request.
} 
which employers learn about the workers' skill at a rate which is assumed to depend on the skill level of the job. ${ }^{25}$ The model predicts that highskill individuals with observable characteristics that are associated with low skill - in our case it would be short physical stature - will tend to be trapped for some time in low-skill jobs. In addition, if the employers' belief on the worker productivity is low enough due to statistical discrimination, ${ }^{26}$ the worker is unlikely to reach the most skill-intensive positions in the economy (Altonji, 2005, p. 115). Indeed, we find that shorter employed workers are systematically less likely to hold a high-skilled position, independently of their education and cognitive abilities.

\footnotetext{
${ }^{25}$ Contrary to the model of Lange (2007), in which the employer learns quickly about workers' productivity but only if workers acquire further education, in the model of Altonji (2005) employers' initial estimate of productivity influences wage growth independently of workers' training.

26 Altonji refers to statistical discrimination on the basis of educational credentials, family background, race and/or ethnicity.
} 


\section{References}

Altonji, J. G. (2005): "Employer Learning, Statistical Discrimination and Occupational Attainment," American Economic Review, 95(2), 112-117.

Altonji, J. G., and R. M. Blank (1999): "Race and Gender in the Labor Market," Discussion paper, Institute for Policy Resarch at Northwestern University.

Altonji, J. G., And C. R. Pierret (2001): "Employer Learning and Statistical Discrimination," Quarterly Journal of Economics, 116(1), 313350 .

Biddle, J. E., And D. S. Hamermesh (1998): "Beauty, Productivity, and Discrimination: Lawyers' Looks and Lucre," Journal of Labor Economics, 16(1), 172-201.

Bielicki, T., And J. Charzewski (1983): "Body Height and Upward Social Mobility," Annals of Human Biology, 10(5), 403-408.

Börsch-Supan, A., And H. Jürges (eds.) (2005): The Survey of Health, Aging, and Retirement in Europe - Methodology. Mannheim Research Institute for the Economics of Aging (MEA).

Brunello, G., M. Fort, And G. Weber (2009): "Changes in Compulsory Schooling, Education and the Distribution of Wages in Europe," The Economic Journal, 119, 516-539.

Cahuc, P., And A. Zylberberg (2004): Labor Economics. The MIT Press.

Case, A., and C. Paxson (2006): "Stature and Status: Height, Ability, and Labor Market Outcomes," Working Paper 12466, NBER.

(2008): "Stature and Status: Height, Ability, and Labor Market Outcomes," Journal of Political Economy, 116(3), 499-532. 
Case, A., C. Paxson, and M. Islam (2008): "Making Sense of the Labor Market Height Premium: Evidence From the British Household Panel Survey," Working Paper 14007, NBER.

Cinnirella, F., M. Piopiunik, and J. Winter (2009): "Why does Height Matter for Educational Attainment? Evidence from German PreTeen Children," mimeo.

De Luca, G., F. Mazzonna, and F. Peracchi (2009): "Aging, cognitive ability and education in Europe," Discussion paper, Paper presented at the American Economic Association meeting, San Francisco, January 3-5, 2009.

Fairlie, R. W., And A. Robb (2007): "Families, Human Capital, and Small Business: Evidence from the Characteristics of Business Owners Survey," Industrial and Labor Relations Review, 60(2), 225-245.

Hamermesh, D. S. (2006): "Changing Looks and Changing 'Discrimination': The Beauty of Economists," Economics Letters, 93(3), 405-412.

Hamermesh, D. S., and J. E. Biddle (1994): "Beauty and the Labor Market," American Economic Review, 84(5), 1174-1194.

Hamermesh, D. S., and A. M. Parker (2003): "Beauty in the Classroom: Professors' Pulchritude and Putative Pedagogical Productivity," Discussion Paper 9853, NBER.

Heineck, G. (2005): "Up in the Skies? The Relationship between Body Height and Earnings in Germany," Labour, 19(3), 469-489.

- (2008): "A Note on the Height-Wage Differential in the UK-CrossSectional Evidence from the BHPS," Economics Letters, 98(3), 288-293.

(2009): "Too tall to be smart? The relationship between height and cognitive abilities," Economics Letters, Forthcoming.

Hensley, W. E. (1993): "Height as a Measure of Success in Academe," Psychology, A Journal of Human Behavior, 30, 40-46. 
HüBleR, O. (2006): "The Nonlinear Link between Height and Wages: An Empirical Investigation," Discussion Paper 2394, IZA.

Judge, T. A., And D. M. Cable (2004): "The Effect of Physical Height on Workplace Success and Income: Preliminary Test of a Theoretical Model," Journal of Applied Psychology, 89(3), 428-441.

LAnge, F. (2007): "The Speed of Employer Learning," Journal of Labor Economics, 25(1), 1-35.

LoH, E. S. (1993): "The Economic Effect of Physical Appearance," Social Science Quarterly, 74, 420-438.

Lynn, R. (1989): "A Nutrition Theory of the Secular Increases in Intelligence, Positive Correlation between Height, Head Size and IQ," British Journal of Education Psychology, 59, 372-377.

Magnusson, P. K., F. Rasmussen, and U. B. Gyllensten (2006): "Height at Age 18 Years Is a Strong Predictor of Attained Education Later in Life: Cohort Study of Over 950000 Swedish Men," International Journal of Epidemiology, 35, 658-663.

OECD (2008): Main Economic Indicators, April 2008. OECD.

Persico, N., A. Postlewaite, and D. Silverman (2004): "The Effect of Adolescent Experience on Labor Market Outcomes: The Case of Height," Journal of Political Economy, 112(5), 1019-1053.

Tanner, J. M. (1989): Foetus into Man: Physical Growth from Conception to Maturity. Harvard University Press.

Young, T. J., And L. A. French (1996): "Height and Preceived Competence of U.S. Presidents," Perceptual and Motor Skills, 82. 
Table 1: Number of observations by country

\begin{tabular}{lcc}
\hline \hline Country & Frequency & Percent \\
\hline Austria & 121 & 2.9 \\
Belgium & 313 & 7.5 \\
Czech Republic & 314 & 7.5 \\
Denmark & 502 & 12.0 \\
France & 342 & 8.2 \\
Germany & 403 & 9.6 \\
Greece & 315 & 7.5 \\
Italy & 307 & 7.3 \\
Netherlands & 369 & 8.8 \\
Poland & 181 & 4.3 \\
Spain & 196 & 4.7 \\
Sweden & 588 & 14.0 \\
Switzerland & 246 & 5.9 \\
\hline Total & 4,197 & 100 \\
\hline \hline
\end{tabular}

Source: SHARE, wave 1 and 2. 
Table 2: Summary statistics

\begin{tabular}{lccccc}
\hline \hline \multirow{2}{*}{ Variable } & \multicolumn{2}{c}{ Employed } & & \multicolumn{2}{c}{ Self-employed } \\
\cline { 2 - 3 } \cline { 5 - 6 } Hourly wage & Mean & Std. dev. & & Mean & Std. dev. \\
Age & 20.42 & 33.64 & & & \\
High education & 55.38 & 4.11 & & 56.34 & 4.37 \\
Tenure (years) & 0.29 & 0.45 & & 0.34 & 0.47 \\
Height in cm & 19.64 & 13.27 & & 21.72 & 11.87 \\
Tall (share) & 176.74 & 7.18 & & 176.36 & 7.02 \\
Obesity & 0.55 & 0.50 & & 0.61 & 0.49 \\
Numeracy level 1 & 0.16 & 0.37 & & 0.16 & 0.37 \\
Numeracy level 2 & 0.08 & 0.27 & & 0.06 & 0.23 \\
Numeracy level 3 & 0.33 & 0.44 & & 0.22 & 0.42 \\
Numeracy level 4 & 0.33 & 0.47 & & 0.36 & 0.48 \\
Good memory & 0.63 & 0.47 & & 0.36 & 0.48 \\
Good fluency & 0.68 & 0.48 & & 0.59 & 0.49 \\
Observations & 3058 & 0.47 & & 0.58 & 0.49 \\
\hline \hline
\end{tabular}

Note: High education indicates individuals with at least a post-secondary education (ISCED code 4, 5, or 6). Tall indicates individuals measuring above the country-specific median. Obesity indicates individuals with BMI $\geq 30$. About numeracy, memory and word fluency, see text.

Source: SHARE, wave 1 and 2. 
Table 3: The effect of height on earnings

\begin{tabular}{|c|c|c|c|c|}
\hline \multirow[t]{2}{*}{ Dependent variable: } & \multicolumn{4}{|c|}{ Log hourly wage } \\
\hline & $(1)$ & $(2)$ & $(3)$ & $(4)$ \\
\hline \multirow[t]{2}{*}{ Tall } & $0.082^{* * *}$ & $0.056^{* * *}$ & $0.052^{* * *}$ & 0.027 \\
\hline & $(0.020)$ & $(0.020)$ & $(0.020)$ & $(0.019)$ \\
\hline \multirow[t]{2}{*}{ Age } & -0.004 & -0.002 & -0.002 & -0.002 \\
\hline & $(0.003)$ & $(0.003)$ & $(0.003)$ & $(0.003)$ \\
\hline \multirow[t]{2}{*}{ High education } & $0.305^{* * *}$ & $0.256^{* * *}$ & $0.250 * * *$ & $0.139 * * *$ \\
\hline & $(0.023)$ & $(0.024)$ & $(0.025)$ & $(0.026)$ \\
\hline \multirow[t]{2}{*}{ Tenure } & $0.006^{* * *}$ & $0.006^{* * *}$ & $0.006^{* * *}$ & $0.005^{* * *}$ \\
\hline & $(0.001)$ & $(0.001)$ & $(0.001)$ & $(0.001)$ \\
\hline \multirow[t]{2}{*}{ Married } & $0.074^{* * *}$ & $0.074^{* * *}$ & $0.069 * * *$ & $0.053^{* *}$ \\
\hline & $(0.026)$ & $(0.026)$ & $(0.026)$ & $(0.025)$ \\
\hline \multirow[t]{2}{*}{ Obesity } & -0.029 & -0.033 & -0.034 & -0.035 \\
\hline & $(0.026)$ & $(0.026)$ & $(0.026)$ & $(0.025)$ \\
\hline \multirow[t]{2}{*}{ Numeracy level 2} & & 0.026 & 0.029 & 0.021 \\
\hline & & $(0.035)$ & $(0.035)$ & $(0.034)$ \\
\hline \multirow[t]{2}{*}{ Numeracy level 3} & & $0.088^{* * *}$ & $0.086^{* *}$ & $0.060^{*}$ \\
\hline & & $(0.034)$ & $(0.034)$ & $(0.033)$ \\
\hline \multirow[t]{2}{*}{ Numeracy level 4} & & $0.167^{* * *}$ & $0.162^{* * *}$ & $0.107 * * *$ \\
\hline & & $(0.036)$ & $(0.036)$ & $(0.035)$ \\
\hline \multirow[t]{2}{*}{ Good memory } & & $0.091^{* * *}$ & $0.088^{* * *}$ & $0.072^{* * *}$ \\
\hline & & $(0.021)$ & $(0.021)$ & $(0.020)$ \\
\hline \multirow[t]{2}{*}{ Good fluency } & & $0.080 * * *$ & $0.078^{* * *}$ & $0.045^{* *}$ \\
\hline & & $(0.022)$ & $(0.022)$ & $(0.021)$ \\
\hline \multirow[t]{2}{*}{ Constant } & $2.322^{* * *}$ & $2.062^{* * *}$ & $1.917^{* * *}$ & $1.977^{* * *}$ \\
\hline & $(0.182)$ & $(0.185)$ & $(0.204)$ & $(0.204)$ \\
\hline Health controls & Yes & Yes & Yes & Yes \\
\hline Industry controls & No & No & Yes & Yes \\
\hline Occupation controls & No & No & No & Yes \\
\hline Country controls & Yes & Yes & Yes & Yes \\
\hline Observations & 3058 & 3058 & 3058 & 3058 \\
\hline R-squared & 0.408 & 0.424 & 0.435 & 0.467 \\
\hline
\end{tabular}

Note: OLS estimates. Standard errors in parentheses; ${ }^{*} \mathrm{p}<0.10,{ }^{* *} \mathrm{p}<0.05,{ }^{* * *}$ $\mathrm{p}<0.01$. Tall indicates individuals measuring above the country-specific median. High education indicates individuals with at least a post-secondary education (ISCED code 4, 5, or 6). Obesity indicates individuals with BMI $\geq 30$. About numeracy, memory and word fluency, see text. 
Table 4: Distribution of skills among employed and self-employed

\begin{tabular}{lrr}
\hline \hline Skill Level & Employed & Self-employed \\
\hline Skill 1 (Manager, Professional) & 963 & 527 \\
& $(27.9)$ & $(46.3)$ \\
Skill 2 (Technician) & 647 & 148 \\
& $(18.8)$ & $(13.0)$ \\
Skill 3 (Service, Crafts, Blue-collar) & 1,510 & 437 \\
& $(44.0)$ & $(38.4)$ \\
Skill 4 (Unskilled) & 320 & 27 \\
& $(9.3)$ & $(2.4)$ \\
\hline Total & 3440 & 1139 \\
\hline \hline
\end{tabular}

Note: Occupational Measures from the Dictionary of Occupational Titles for 1980 Census Detailed Occupations. See Case and Paxson (2006, p. 26-27). 
Table 5: The effect of height on employed occupational sorting

\begin{tabular}{|c|c|c|c|}
\hline \multirow[b]{2}{*}{ Dependent variable: } & \multicolumn{3}{|c|}{ Employed } \\
\hline & Skill 1 & Skill 2 & Skill 4 \\
\hline \multirow[t]{2}{*}{ Tall } & $1.648^{* * *}$ & $1.312^{* * *}$ & 0.855 \\
\hline & $(0.178)$ & $(0.138)$ & $(0.114)$ \\
\hline \multirow[t]{2}{*}{ Age } & 1.007 & 1.010 & $1.033^{* *}$ \\
\hline & $(0.014)$ & $(0.014)$ & $(0.017)$ \\
\hline \multirow[t]{2}{*}{ High education } & $9.213^{* * *}$ & $3.403^{* * *}$ & 0.748 \\
\hline & $(1.145)$ & $(0.450)$ & $(0.170)$ \\
\hline \multirow[t]{2}{*}{ Tenure } & $1.010^{* *}$ & $1.019^{* * *}$ & $0.971^{* * *}$ \\
\hline & $(0.004)$ & $(0.004)$ & $(0.005)$ \\
\hline \multirow[t]{2}{*}{ Married } & $1.548^{* * *}$ & $1.381^{* *}$ & 0.991 \\
\hline & $(0.228)$ & $(0.197)$ & $(0.172)$ \\
\hline \multirow[t]{2}{*}{ Obesity } & 0.976 & 0.942 & 0.832 \\
\hline & $(0.147)$ & $(0.134)$ & $(0.148)$ \\
\hline \multirow[t]{2}{*}{ Numeracy level 2} & 1.336 & $1.552^{*}$ & 0.997 \\
\hline & $(0.338)$ & $(0.360)$ & $(0.204)$ \\
\hline \multirow[t]{2}{*}{ Numeracy level 3} & $2.059 * * *$ & $2.122^{* * *}$ & 0.848 \\
\hline & $(0.503)$ & $(0.479)$ & $(0.176)$ \\
\hline \multirow[t]{2}{*}{ Numeracy level 4} & $3.451^{* * *}$ & $2.684^{* * *}$ & 0.759 \\
\hline & $(0.854)$ & $(0.628)$ & $(0.182)$ \\
\hline \multirow[t]{2}{*}{ Good memory } & $1.359^{* * *}$ & $1.389^{* * *}$ & $0.705^{* *}$ \\
\hline & $(0.158)$ & $(0.155)$ & $(0.096)$ \\
\hline \multirow[t]{2}{*}{ Good fluency } & $1.774^{* * *}$ & $1.661^{* * *}$ & $0.760^{*}$ \\
\hline & $(0.223)$ & $(0.197)$ & $(0.107)$ \\
\hline Health controls & Yes & Yes & Yes \\
\hline Industry controls & Yes & Yes & Yes \\
\hline Country controls & Yes & Yes & Yes \\
\hline Observations & 3440 & & \\
\hline Pseudo R-squared & 0.219 & & \\
\hline
\end{tabular}

Note: Multinomial logit model: Relative Risk Ratios (RRR) reported. Standard errors in parentheses. The base category is Skill 3. ${ }^{*} \mathrm{p}<0.10,{ }^{* *} \mathrm{p}<0.05$, $* * * \mathrm{p}<0.01$. Tall indicates individuals measuring above the country-specific median. High education indicates individuals with at least a post-secondary education (ISCED code 4, 5, or 6). Obesity indicates individuals with BMI $\geq 30$. About numeracy, memory and word fluency, see text. 
Table 6: The effect of height on self-employed occupational sorting

\begin{tabular}{lccc}
\hline \hline & & Self-employed & \\
Dependent variable: & Skill 1 & Skill 2 & Skill 4 \\
\hline Tall & 1.064 & 1.165 & 0.603 \\
& $(0.160)$ & $(0.253)$ & $(0.257)$ \\
Age & 1.011 & 1.019 & 0.921 \\
& $(0.018)$ & $(0.025)$ & $(0.050)$ \\
High education & $4.931^{* * *}$ & $3.000^{* * *}$ & 1.783 \\
& $(0.858)$ & $(0.709)$ & $(0.991)$ \\
Tenure & $0.985^{* *}$ & $0.965^{* * *}$ & $0.946^{* * *}$ \\
& $(0.007)$ & $(0.009)$ & $(0.018)$ \\
Married & 0.738 & 0.847 & 0.481 \\
& $(0.154)$ & $(0.241)$ & $(0.257)$ \\
Obesity & 0.819 & 0.930 & 1.322 \\
& $(0.166)$ & $(0.285)$ & $(0.689)$ \\
Numeracy level 2 & 1.264 & 2.543 & 1.665 \\
Numeracy level 3 & $(0.402)$ & $(1.504)$ & $(1.426)$ \\
& 1.111 & 2.132 & 1.752 \\
Numeracy level 4 & $(0.340)$ & $(1.225)$ & $(1.475)$ \\
& $1.804^{*}$ & $3.558^{* *}$ & 0.578 \\
Good memory & $(0.564)$ & $(2.052)$ & $(0.573)$ \\
Good fluency & 1.166 & $1.545^{*}$ & 0.914 \\
Health controls & $(0.177)$ & $(0.347)$ & $(0.392)$ \\
Country controls & 0.952 & $0.610^{* *}$ & $0.405^{*}$ \\
Observations & $(0.155)$ & $(0.144)$ & $(0.198)$ \\
Pseudo R-squared & Yes & Yes & Yes \\
\hline \hline
\end{tabular}

Note: Multinomial logit model: Relative Risk Ratios (RRR) reported. Standard errors in parentheses. The base category is Skill 3. ${ }^{*} \mathrm{p}<0.10,{ }^{* *} \mathrm{p}<0.05$, *** $\mathrm{p}<0.01$. Tall indicates individuals measuring above the country-specific median. High education indicates individuals with at least a post-secondary education (ISCED code 4, 5, or 6). Obesity indicates individuals with BMI $\geq 30$. About numeracy, memory and word fluency, see text. 
Table 7: The effect of height on being an employed or self-employed professional

\begin{tabular}{|c|c|c|}
\hline & $\begin{array}{c}\text { Employed } \\
\text { professionals }\end{array}$ & $\begin{array}{l}\text { Self-employed } \\
\text { professionals }\end{array}$ \\
\hline \multirow[t]{2}{*}{ Tall } & $0.111^{*}$ & -0.001 \\
\hline & $(0.063)$ & $(0.108)$ \\
\hline \multirow[t]{2}{*}{ Age } & $-0.019^{* *}$ & $0.033^{* * *}$ \\
\hline & $(0.008)$ & $(0.012)$ \\
\hline \multirow[t]{2}{*}{ High education } & $1.134^{* * *}$ & $1.419^{* * *}$ \\
\hline & $(0.064)$ & $(0.110)$ \\
\hline \multirow[t]{2}{*}{ Tenure } & $0.006^{* *}$ & $-0.008^{*}$ \\
\hline & $(0.003)$ & $(0.005)$ \\
\hline \multirow[t]{2}{*}{ Married } & -0.081 & $-0.350^{* *}$ \\
\hline & $(0.084)$ & $(0.136)$ \\
\hline \multirow[t]{2}{*}{ Obesity } & -0.148 & -0.142 \\
\hline & $(0.094)$ & $(0.159)$ \\
\hline \multirow[t]{2}{*}{ Numeracy level 2} & 0.187 & -0.056 \\
\hline & $(0.162)$ & $(0.285)$ \\
\hline \multirow[t]{2}{*}{ Numeracy level 3} & $0.357^{* *}$ & 0.184 \\
\hline & $(0.158)$ & $(0.269)$ \\
\hline \multirow[t]{2}{*}{ Numeracy level 4} & $0.517^{* * *}$ & 0.283 \\
\hline & $(0.158)$ & $(0.269)$ \\
\hline \multirow[t]{2}{*}{ Good memory } & 0.029 & $0.184^{*}$ \\
\hline & $(0.069)$ & $(0.112)$ \\
\hline \multirow[t]{2}{*}{ Good fluency } & $0.149^{*}$ & -0.107 \\
\hline & $(0.076)$ & $(0.120)$ \\
\hline \multirow[t]{2}{*}{ Constant } & $-1.415^{* * *}$ & $-3.298^{* * *}$ \\
\hline & $(0.485)$ & $(0.798)$ \\
\hline Health controls & Yes & Yes \\
\hline Country controls & Yes & Yes \\
\hline Observations & 3440 & 1139 \\
\hline Pseudo R-squared & 0.226 & 0.257 \\
\hline
\end{tabular}

Note: Probit model, standard errors in parenthesis. ${ }^{*} \mathrm{p}<0.10,{ }^{* *} \mathrm{p}<0.05,{ }^{* * *}$ $\mathrm{p}<0.01$. Tall indicates individuals measuring above the country-specific median. High education indicates individuals with at least a post-secondary education (ISCED code 4, 5, or 6). Obesity indicates individuals with BMI $\geq 30$. About numeracy, memory and word fluency, see text. 
Figure 1: Log hourly wage and height by country

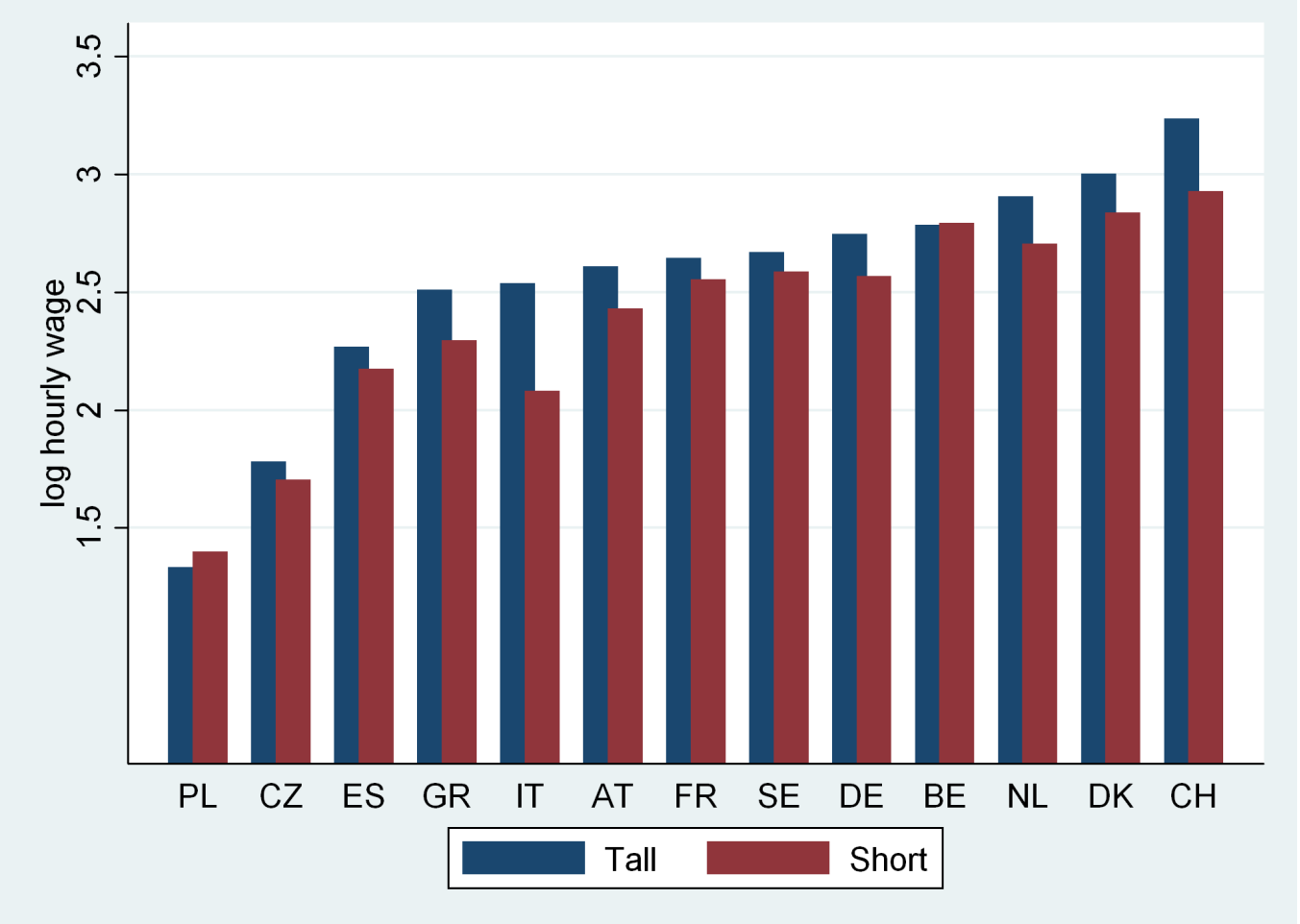

Note: Employed workers who reported an income from work. Tall (short) indicates individuals measuring above (below) the country-specific median.

Source: SHARE, wave 1 and 2. 
Figure 2: Height and education by country

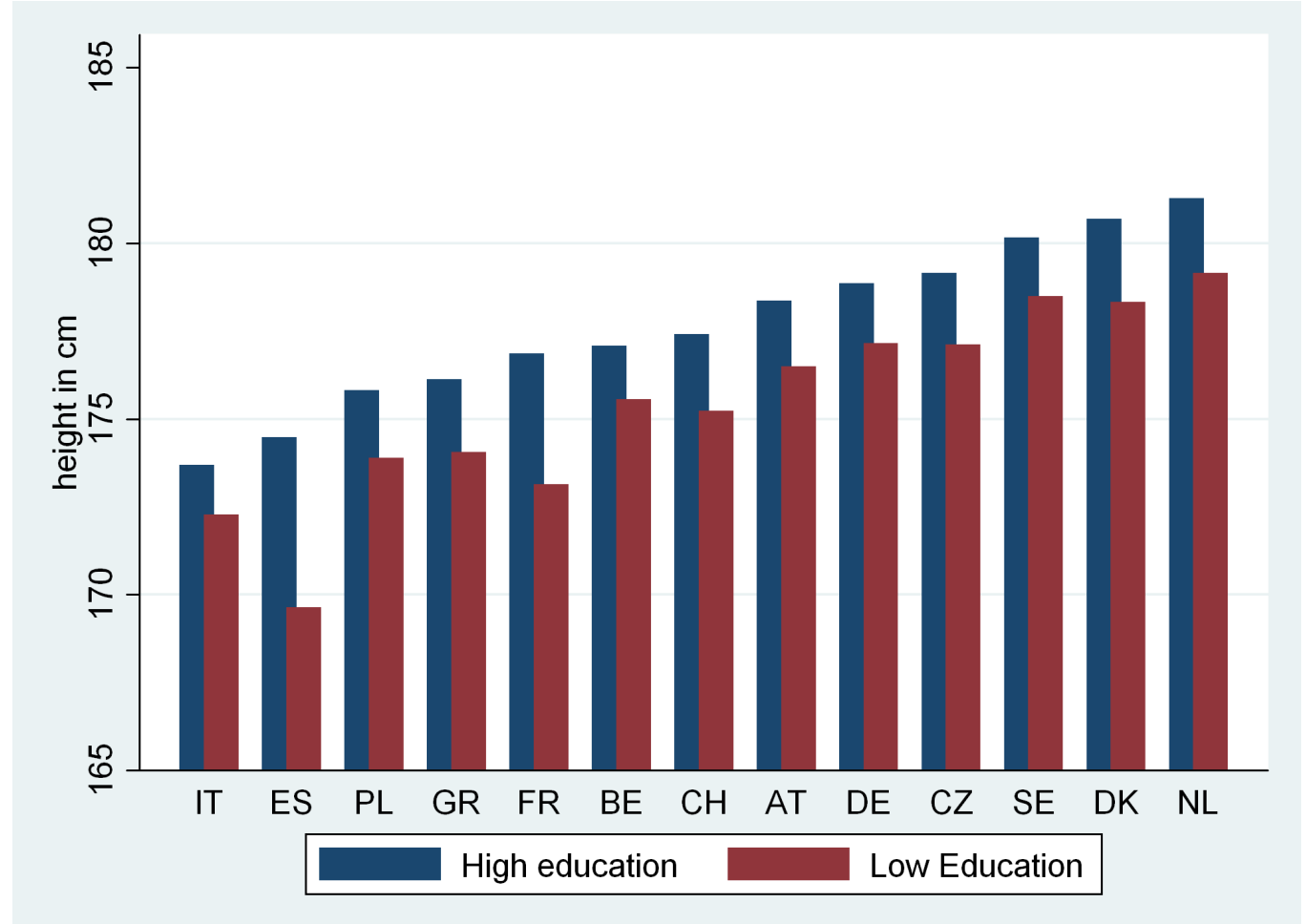

Note: Employed and self-employed. High (low) education indicates individuals having (not having) attained at least a post-secondary education (ISCED code 4, 5 , or 6$)$.

Source: SHARE, wave 1 and 2. 
Figure 3: Cognitive functions and height
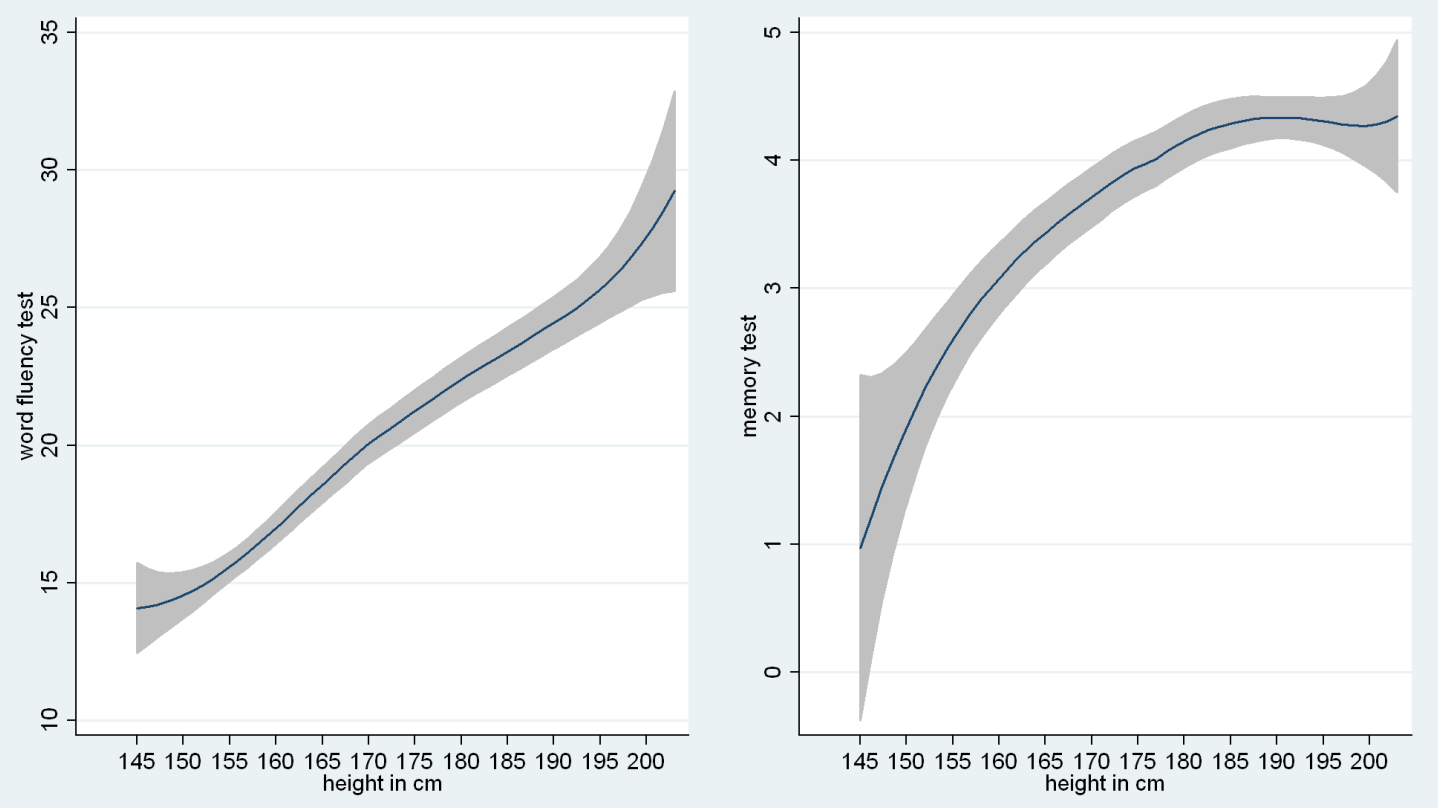

Note: Employed and self-employed. Data points are fitted with a second order polynomial Kernel function. The bands show a 95 percent confidence interval. Source: SHARE, wave 1 and 2. 
Figure 4: Distributions of height and cognitive functions for employed and self-employed professionals
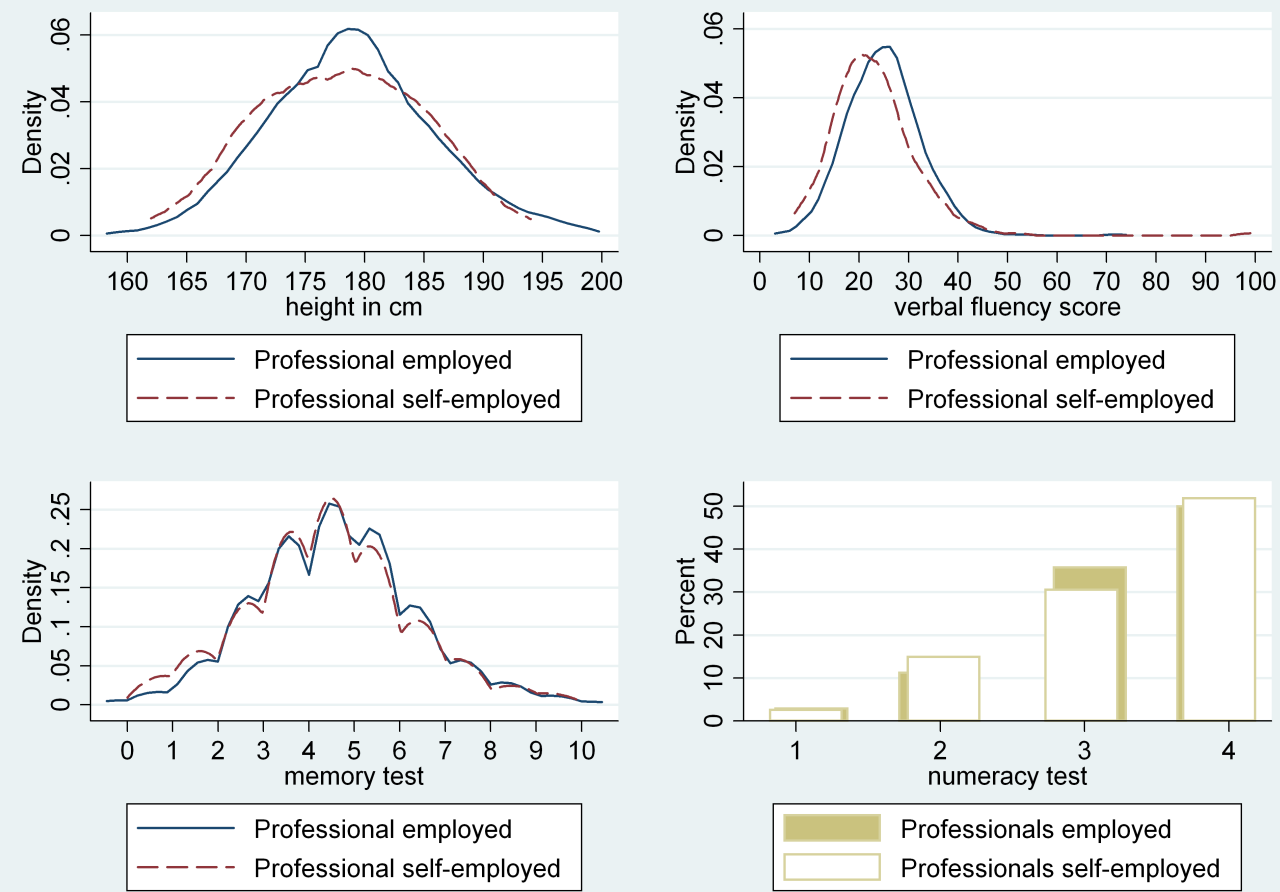

Source: SHARE, wave 1 and 2. 


\section{Discussion Paper Series}

Mannheim Research Institute for the Economics of Aging, Universität Mannheim

To order copies, please direct your request to the author of the title in question.

\begin{tabular}{|c|c|c|c|}
\hline Nr. & Autoren & Titel & Jahr \\
\hline $173-09$ & Michael Ziegelmeyer & $\begin{array}{l}\text { Documentation of the logical imputation using } \\
\text { the panel structure of the 2003-2008 German } \\
\text { SAVE Survey }\end{array}$ & 09 \\
\hline $174-09$ & $\begin{array}{l}\text { Axel Börsch-Supan, } \\
\text { Tabea Bucher-Koenen, } \\
\text { Martin Gasche und } \\
\text { Christina Benita Wilke }\end{array}$ & $\begin{array}{l}\text { Ein einheitliches Rentensystem für } \\
\text { Ost- und Westdeutschland - } \\
\text { Simulationsrechnungen zum Reformvorschlag } \\
\text { des Sachverständigenrates }\end{array}$ & 09 \\
\hline $175-09$ & $\begin{array}{l}\text { Steffen Reinhold, } \\
\text { Hendrik Jürges }\end{array}$ & Parental Income and Child Health in Germany & 09 \\
\hline $176-09$ & $\begin{array}{l}\text { Karsten Hank, Marcel } \\
\text { Erlinghagen }\end{array}$ & $\begin{array}{l}\text { Perceptions of Job Security in Europe's Ageing } \\
\text { Workforce }\end{array}$ & 09 \\
\hline $177-09$ & $\begin{array}{l}\text { Hendrik Jürges, } \\
\text { Karsten Hank, }\end{array}$ & $\begin{array}{l}\text { The Last Year of Life in Europe: Initial findings } \\
\text { from the SHARE study }\end{array}$ & 09 \\
\hline $178-09$ & Steffen Reinhold & $\begin{array}{l}\text { Reassessing the Link between Premarital } \\
\text { Cohabitation and Marital Instability }\end{array}$ & 09 \\
\hline $179-09$ & $\begin{array}{l}\text { Alexander Ludwig, } \\
\text { Edgar Vogel }\end{array}$ & $\begin{array}{l}\text { Mortality, Fertility, Education and Capital } \\
\text { Accumulation in a simple OLG Economy }\end{array}$ & 09 \\
\hline $180-09$ & Edgar Vogel & $\begin{array}{l}\text { From Malthus to Modern Growth: Child Labor, } \\
\text { Schooling and Human Capital }\end{array}$ & 09 \\
\hline $181-09$ & $\begin{array}{l}\text { Steffen Reinhold, } \\
\text { Hendrik Jürges }\end{array}$ & $\begin{array}{l}\text { Secondary School Fees and the Causal Effect } \\
\text { of Schooling on Health Behaviour }\end{array}$ & 09 \\
\hline $182-09$ & $\begin{array}{l}\text { Steffen Reinhold, } \\
\text { Kevin Thom }\end{array}$ & $\begin{array}{l}\text { Temporary Migration and Skill Upgrading: } \\
\text { Evidence from Mexican Migrants }\end{array}$ & 09 \\
\hline $183-09$ & $\begin{array}{l}\text { Hendrik Jürges, } \\
\text { Eberhard Kruk, Steffen } \\
\text { Reinhold }\end{array}$ & $\begin{array}{l}\text { The effect of compulsory schooling on health - } \\
\text { evidence from biomarkers }\end{array}$ & 09 \\
\hline $184-09$ & $\begin{array}{l}\text { Nicola Fuchs- } \\
\text { Schündeln, Dirk } \\
\text { Krüger, Mathias } \\
\text { Sommer } \\
\end{array}$ & $\begin{array}{l}\text { Inequality Trends for Germany in the Last Two } \\
\text { Decades: A Tale of Two Countries }\end{array}$ & 09 \\
\hline $185-09$ & $\begin{array}{l}\text { Francesco Cinnirella, } \\
\text { Joachim Winter }\end{array}$ & $\begin{array}{l}\text { Size Matters! Body Height and Labor Market } \\
\text { Discrimination: A Cross-European Analysis }\end{array}$ & 09 \\
\hline
\end{tabular}

